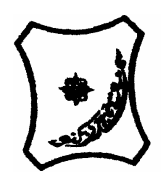

Bayero Journal of Pure and Applied Sciences, 9(1): 11 - 18

Received:

Accepted:

ISSN $2006-6996$

\title{
SEASONAL VARIATIONS IN THE PROXIMATE COMPOSITIONS OF FIVE ECONOMICALLY- IMPORTANT FISH SPECIES FROM LAKE VICTORIA AND LAKE TANGANYIKA, TANZANIA
}

\author{
* Abdulkarim, B. ${ }^{1,2}$, Bwathondi, P.O.J. ${ }^{2}$ and Benno, B. L. ${ }^{2}$ \\ ${ }^{1}$ Department of Biology, Umaru Musa Yar'adua University, Katsina State, Nigeria. \\ ${ }^{2}$ Department of Aquatic Sciences and Fisheries Technology, \\ University of Dar es salaam, Tanzania. \\ *Correspondence author :bbmohammed911@yahoo.com
}

\begin{abstract}
Proximate compositions of five economically-important fish species from Lake Victoria and Lake Tanganyika, Tanzania were determined using standard methods and procedures of the Association of the Analytical Chemists. Samples of Lates niloticus, Oreochromis niloticus, Rastrineobola argentea, Limnothrissa miodon and Stolothrissa tanganicae were collected during the dry and rainy seasons (December 2012 to March 2013) and (June to September, 2013). Protein contents (17.35$21.44 \mathrm{~g} / 100 \mathrm{~g})$ were significant/y $(p<0.05)$ higher in wet seasons and lower $(16.13-19.77 \mathrm{~g} / 100$ $g)$ during the dry season in all the species. Similarly, lipids contents were significantly $(p<0.05)$ higher during the wet seasons $(1.01-3.19 \mathrm{~g} / 100 \mathrm{~g})$ and lower $(0.79-1.79 \mathrm{~g} / 100 \mathrm{~g})$ during the dry season in all the species, while carbohydrate $(1.89-4.46 \mathrm{~g} / 100 \mathrm{~g})$ was significantly $(p<0.05)$ higher during the dry season in all the species. The present study showed that these species are good sources of protein in desirable quantities for normal growth, development and as a remedy to nutritional and health related problems. High contents of protein and lipid during wet season make the fish species desirable for consumption during this period. These fish species are therefore recommended to diabetic consumers due to their low carbohydrate contents.
\end{abstract}

Key words: Fish species, Lake Victoria, Lake Tanganyika, Proximate, Seasonal variations.

\section{INTRODUCTION}

The measurement of proximate compositions such as protein, carbohydrates, lipids, moisture contents and ash percentage in fish is necessary to ensure that they meet the requirements of food regulations and commercial specifications (Waterman, 2000), as well as being important to consumers, scientists and manufacturers for many aspects including nutritional value and considerations regarding processing (Murray and Burt, 2001).)

Fish has made important contributions to micro nutrient supplies such as protein, vitamins, minerals, amino acids and fatty acids (Lake, 1984; Tobor, 1984; FAO, 2000). Fish oil contains vitamins A, D, E and $K$ which have been successfully used in controlling cardiovascular diseases, asthma, arthritis, arteriosclerosis, auto-immune deficiency diseases and tumours (Ackman, 1989; Bhuiyan et. al., 1993). Previous researches have shown that fish play vital roles in prevention and management of many diseases such as heart disorders and neurological diseases. High percentages of poly unsaturated fatty acids (PUFA) found in fish are important in lowering blood cholesterol level (Kent, 1984). Increased intake of fishes reduces sudden death from heart attacks, improves symptoms of rheumatoid arthritis, decreases the risk of bowel cancer; reduce insulin resistance in the skeletal muscles, as well as vital for normal development of foetus in pregnant women (Conquer and Holub, 2002).

Principal compositions of fish are 16 to $21 \%$ protein, 0.2 to $2.5 \%$ fat, 1.2 to $1.5 \%$ mineral, 0.0 to $0.5 \%$ carbohydrates and 66 to $81 \%$ water (Love, 1980). The composition however, varies greatly from species to species and also from individual to individual depending on age, sex, environment and seasons (Huss, 1988, 1995). According to Noel et al. (2011) the biochemical compositions in fishes are known to vary with season, size, stage of maturity, availability of food and so forth. Furthermore, variations in proximate compositions of fish are related to feeding intake. During periods of heavy feeding, the protein content of muscle tissue increases slightly at first then the fat content may show a marked and rapid increase (Huss, 1988). On the other hand, fish may have starvation periods for natural or physiological reasons (spawning or migration) or due to some external forces such as shortage of food. In that case, fat content gradually decreases and then a decline in protein may also be seen (Huss, 1988, 1995).

Seasonal variations in proximate compositions of fishes have been investigated in various parts of the world. For instance; Abdullahi and Abolude (2000) studied the effects of season on the nutrient contents of families cichlidae and claridae in Northern Nigeria. 
Abdullahi (2005) studied the seasonal variability of Malapterus electricus from Niger- Benue confluence, Tzikas et al. (2007) studied the seasonal variations in chemical compositions of Trachurus mediterranean and Abdulkarim et al. (2011) studied the seasonal variations in the proximate and mineral contents of three fresh water fishes of the families Mochokidae, Mormoryridae and Schilbedae from Mairuwa Reservoir, Faskari, Katsina state Nigeria.

Lake Victoria and Lake Tanganyika are among the great fresh water lakes of the world and are blessed with commercially important species of fishes, most prominent among them are L. niloticus (Linnaeus), $O$. niloticus (Linnaeus), Rastrineobola argentea (Pellegrin), Stolothrissa tanganicae (Pellegrin) and Limnothrissa miodon (Boulenger), but very little studies have been done with regards to the effect of seasons on their proximate compositions. The fishes are common and acceptable to consumers in the local and international markets and are highly relished by the people. The objective of this study was therefore to determine seasonal variations in the proximate contents of these important fishes. A hypothesis that there were significant seasonal variations in proximate compositions among the five fish species was postulated.

\section{MATERIALS AND METHODS}

Study Areas

Lake Victoria, covering an area of $68,800 \mathrm{~km}^{2}$ is the second largest lake in the world after Lake Superior in North America. It is shared by the three East African countries with Tanzania occupying the largest portion as follows, Tanzania (51 \%), Uganda (43\%) and Kenya (6\%). (Fig.1). The lake lies between latitude $0.7 \circ \mathrm{N}-3^{\circ} \mathrm{S}$ and Longitude of $31.8^{\circ} \mathrm{E}-34.8^{\circ} \mathrm{E}$ (Witte and Van Densen, 1994).

Lake Tanganyika is located between latitude $3^{\circ} 20^{\prime}$ and $8^{\circ} 48^{\prime} \mathrm{S}$ and between longitude $29^{\circ} 03^{\prime}$ and $31^{\circ}$ $12^{\prime} \mathrm{E}$ (Sven et al., 2006). The riparian countries that shared the lake in terms of surface area are Burundi
(8\%), Democratic Republic of Congo (45 \%), Tanzania (41 \%) and Zambia (6\%) (Fig.1.).

\section{Samples collection and Processing}

A total of 11,584 samples of the five fish species consisting of 226 L. niloticus, 237 O. niloticus and 4865 of $R$. argentea were purchased randomly from the commercial catches of fishermen at the three sampling sites (i.e. Mwanza, Magu and Sengerema) of Lake Victoria, and $4320 \mathrm{~S}$. tanganicae, $1936 \mathrm{~L}$. miodon from ( Kibirizi, Katonga and Kigoma) from lake Tanganyika. (Fig.1). The fishes were purchased in the early morning between 06:30 - 08:30 hours of December 2012, January, February, March, 2013 (wet season) and June, July, August and September 2013 (dry season). Each time the fishes were purchased from the fishermen they were iced and transported in insulated cool boxes to the Department of Aquatic Sciences and Fisheries University of Dar es salaam and prepared for further laboratory analysis.

Twenty (20) samples each of L. niloticuS, O. niloticus, 250 samples of $R$. argentea, $S$. tanganicae and 150 samples of $L$. miodon were chosen monthly and randomly from the population for further preparations. All the fish samples were individually measured to standard length in $\mathrm{cm}$ with a ruler and weighed to the nearest gram with an electrical weighing balance LCD series (Model number: YP 500 IN). The samples were washed with de-iodized water, filleted, de- boned for the big species ( $L$. niloticus and $O$. niloticus), pooled and oven-dried at $105-109^{\circ} \mathrm{C}$ for 24 hours or to a constant weight before being milled into homogenous powder using $8^{\prime \prime}$ Lab. milling machine (Christy Hunt Engineering Essex, England Serial number 19911). Powdered samples were put in polythene bags, labelled and kept in a dry place before being transported to the Department of Animal Sciences and Production (DASP), Sokoine University of Agriculture (SUA), Morogoro where the analyses were carried out. Triplicate determinations were carried out on each sample.

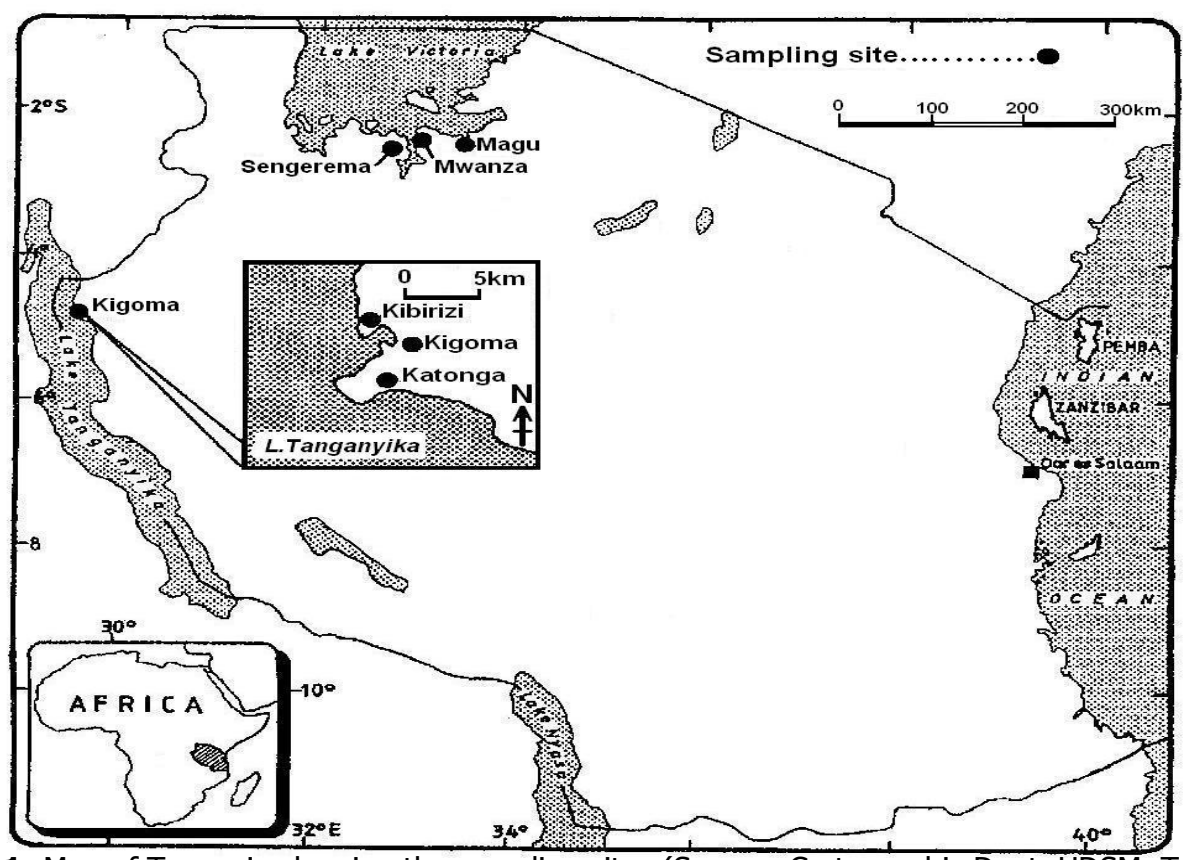

Figure 1: Map of Tanzania showing the sampling sites (Source: Cartographic Dept. UDSM, Tanzania). 


\section{Proximate analyses}

The proximate compositions (moisture, crude protein, lipid, carbohydrates and ash) of the five fish species were determined using the standard methods of the Association of Official Analytical Chemists (AOAC, 1990). Moisture content was determined based on the differences between the wet weight and the weight after drying to a constant temperature at $\left(100^{\circ} \mathrm{C}\right)$. The protein content was determined in three stages: digestion, distillation and titration by micro-kjeldhal method and multiplied by 6.25 to estimate the crude protein content (AOAC, 1990). The lipid was determined by extraction with petroleum ether in a Soxhlet extractor for 4-8 hours, while the crude carbohydrate was calculated by the difference method (AOAC, 1990). The ash content was determined when the white ash was formed and a constant weight maintained. Ten grams of dried powder was placed in a pre-weighed porcelain crucible and ignited in an ashing furnace maintained at $600^{\circ} \mathrm{C}$ until a constant weight was obtained.

\section{Statistical analyses}

The data obtained were subjected to a t-test and Wilcoxon matched- paired signed rank test using Graph pad Prism statistical software Version (6.04) at a significant difference level of $\mathrm{P}>0.05$.

\section{RESULTS}

The lengths and weights measurements of the five studied fishes are given in Table 1 . The average lengths of the fishes ranged widely from 4.68 to $126.04 \mathrm{~cm}$. The average weights of the species ranged from 1.75 to $1872 \mathrm{~g}$. Literatures have shown that all the species are in matured stages.

Table 1: Lengths and weights measurement of the investigated fish species of Lake Victoria and Lake Tanganyika, Tanzania

\begin{tabular}{lllllll}
\hline S/ No & Specie & $\begin{array}{l}\text { Local } \\
\text { name }\end{array}$ & $\begin{array}{l}\text { Common } \\
\text { name }\end{array}$ & $\begin{array}{l}\text { Average } \\
\text { length }(\mathrm{cm})\end{array}$ & $\begin{array}{l}\text { Average } \\
\text { weight }(\mathrm{g})\end{array}$ & Examined part \\
\hline 1 & L. niloticus & Sangara & Nile Perch & $126.04 \pm 8.9$ & $1872 \pm 158$ & Flesh \\
2 & O. niloticus & Sato & Tilapia & $29.49 \pm 2.9$ & $807.62 \pm 541$ & Flesh \\
3 & R. argentea & Dagaa & Sardine & $4.68 \pm 0.63$ & $1.75 \pm 1.44$ & Whole* \\
4 & L. miodon & Dagaa & Sardine & $11.45 \pm 10.8$ & $6.84 \pm 1.43$ & Whole* $^{*}$ \\
5 & S. tanganicae & Dagaa & Sardine & $7.51 \pm 0.76$ & $3.23 \pm 3.49$ & Whole* $^{*}$ \\
\hline
\end{tabular}

* Flesh, bone, skin head

The seasonal variations in the proximate compositions of the five investigated fish species is shown in Table 2. The mean protein content of L. niloticus during the wet season was $20.87 \mathrm{~g} / 100 \mathrm{~g}$ and that of the dry season was $16.28 \mathrm{~g} / 100 \mathrm{~g}$. The content was significantly higher in wet season than the dry season
(Two sample paired $t$-test, $t=8.891$, df $11, p$ $<0.0001$ ) (Fig. 2A). The mean lipid content during wet season was $3.18 \mathrm{~g} / 100 \mathrm{~g}$ and that of dry season was $1.79 \mathrm{~g} / 100 \mathrm{~g}$. The content was significantly higher in wet season than the dry season (Two sample paired $\mathrm{t}-$ test, $\mathrm{t}=5.786, \mathrm{df}=11, \mathrm{p}$ $=<0.0001$ ) (Fig.2 B).

Table 2: Seasonal variations in the proximate compositions of the investigated fish species from Lake Victoria and Lake Tanganyika in $\mathrm{g} / 100 \mathrm{~g}$

\begin{tabular}{lccccc}
\hline Sish & Protein & Lipid & Carbohydrate & Moisture & Ash \\
\hline L. niloticus & i $20.87 \pm 1.64$ & $3.18 \pm 0.98$ & $1.80 \pm 1.05$ & $70.27 \pm 2.97$ & $3.86 \pm 0.89$ \\
& ii $16.28 \pm 0.35$ & $1.79 \pm 0.31$ & $4.46 \pm 1.17$ & $72.07 \pm 1.20$ & $5.39 \pm 0.59$ \\
O. niloticus & i $21.44 \pm 1.58$ & $2.76 \pm 0.90$ & $1.19 \pm 0.28$ & $71.17 \pm 1.81$ & $3.56 \pm 0.34$ \\
& ii $17.71 \pm 1.31$ & $1.19 \pm 1.11$ & $3.06 \pm 1.04$ & $73.45 \pm 1.12$ & $4.61 \pm 0.51$ \\
R. argentea & i $19.61 \pm 1.59$ & $1.20 \pm 0.43$ & $1.17 \pm 0.71$ & $71.52 \pm 1.26$ & $6.52 \pm 1.14$ \\
& ii $16.13 \pm 0.69$ & $0.41 \pm 0.32$ & $2.15 \pm 0.37$ & $76.87 \pm 0.53$ & $4.44 \pm 0.57$ \\
L. miodon & i $17.35 \pm 1.54$ & $1.01 \pm 0.58$ & $1.35 \pm 0.28$ & $75.10 \pm 0.45$ & $6.08 \pm 0.83$ \\
& ii $16.72 \pm 0.98$ & $0.79 \pm 0.39$ & $1.89 \pm 0.40$ & $70.56 \pm 1.06$ & $6.87 \pm 2.51$ \\
S. tanganicae & i $19.77 \pm 2.81$ & $1.58 \pm 0.24$ & $1.19 \pm 0.67$ & $70.56 \pm 1.06$ & $6.87 \pm 2.51$ \\
& ii $16.12 \pm 0.54$ & $1.15 \pm 0.19$ & $3.57 \pm 0.58$ & $71.52 \pm 0.68$ & $7.54 \pm 0.83$ \\
\hline
\end{tabular}

i- Rainy season

ii-Dry season

The mean carbohydrate content during the wet season was $1.80 \mathrm{~g} / 100 \mathrm{~g}$ and $4.46 \mathrm{~g} / 100 \mathrm{~g}$ during the dry season. The content was significantly higher in dry season than the wet season (Wilcoxon matchedpaired signed rank test, $W=78, d f=11, p=0.0005$ )
(Fig.2C). Interestingly, there were no significant differences in the moisture contents between the two seasons (Two sample paired $\mathrm{t}-$ test, $\mathrm{t}=2.090$, $\mathrm{df}=$ $11, p=0.0007$ ) (Fig. 2D). 
Bajopas Volume 9 Number 1 June, 2016

The mean moisture content during the wet season was $70.27 \mathrm{~g} / 100 \mathrm{~g}$ and $72.07 \mathrm{~g} / 100 \mathrm{~g}$ during the dry season. The mean ash content of the species during the wet season was $3.86 \mathrm{~g} / 100 \mathrm{~g}$ and $5.39 \mathrm{~g} / 100 \mathrm{~g}$
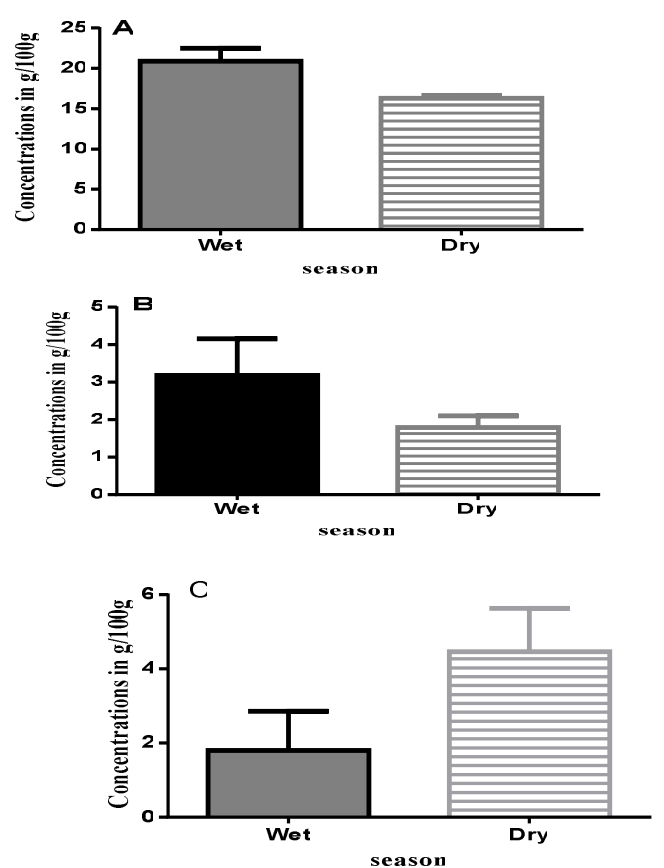

Figure 2: Seasonal variation in protein (A), Lipid (B), Carbohydrate (C), Moisture (D) and ash (E) in L. niloticus from Lake Victoria.

The mean protein content of $O$. niloticus during the wet season was $21.44 \mathrm{~g} / 100 \mathrm{~g}$ and $17.71 \mathrm{~g} / 100 \mathrm{~g}$ during the dry season. The protein content was significantly higher in wet season than the dry season (Wilcoxon matched pair signed rank test, $\mathrm{W}=-66$, $\mathrm{df}=11, \mathrm{p}=0.0068$ ) (Fig. $3 \mathrm{~A}$ ). The mean lipid content was significantly higher in wet season than dry season (Two sampled paired $t$ - test, $t=4.087, d f=11, p=$ 0.0018) (Fig. 3B). The content was $2.76 \mathrm{~g} / 100 \mathrm{~g}$ during the wet season and $1.19 \mathrm{~g} / 100 \mathrm{~g}$ during the dry season. The mean carbohydrate content was significantly higher in dry season than wet season (Two sample $t$ - test, $t=5.206, d f=11, p=0.0003$ )
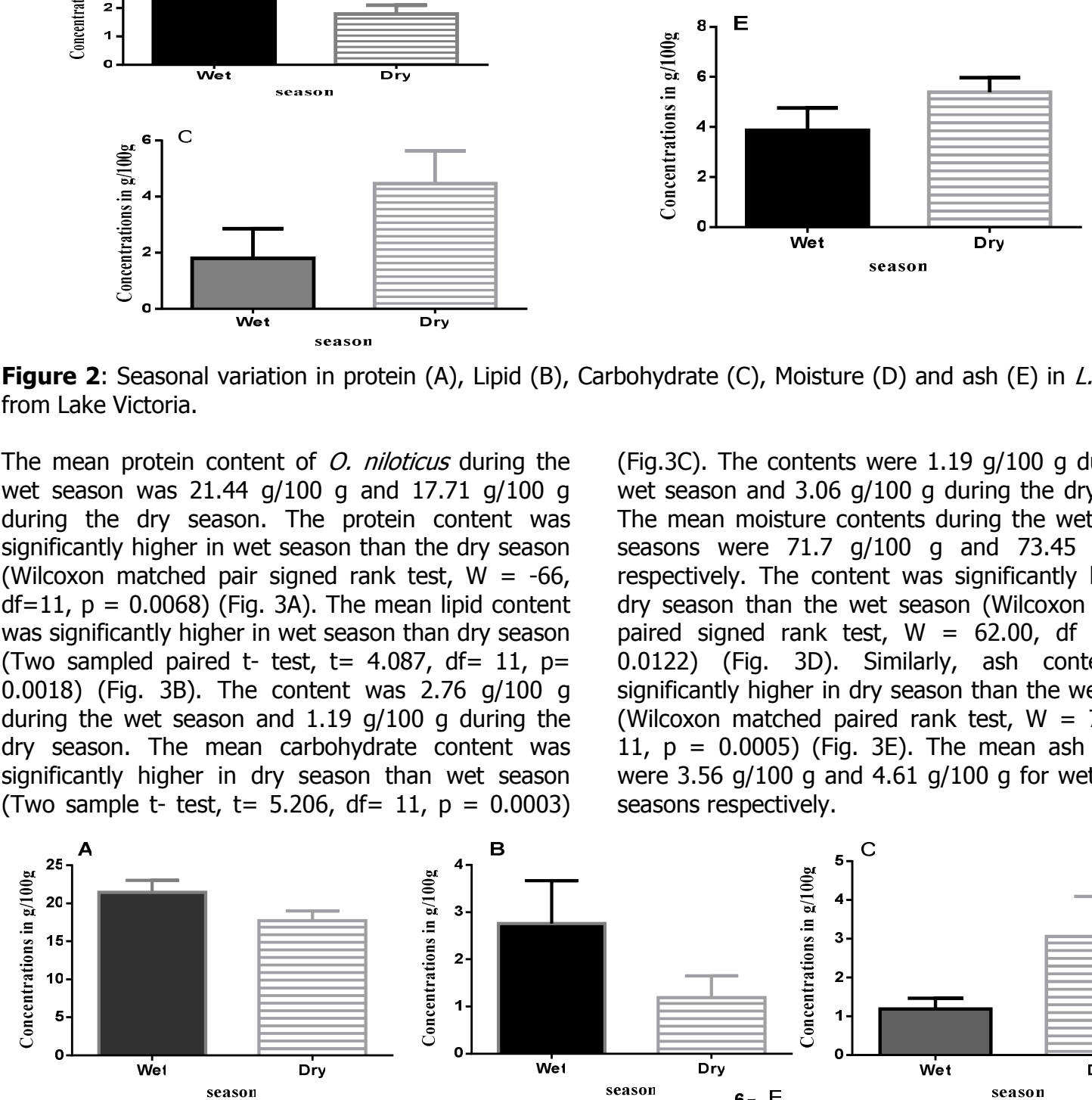
test, $\mathrm{t}=4.867, \mathrm{df}=11, \mathrm{p}=0.0007$ ) (Fig.2E).

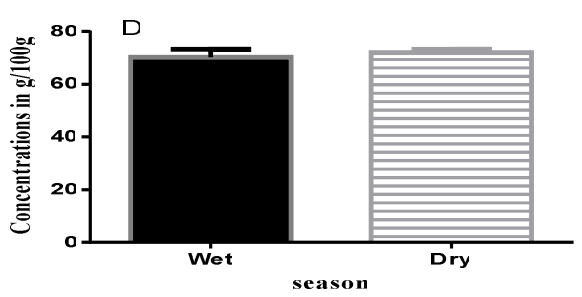

(Fig.3C). The contents were $1.19 \mathrm{~g} / 100 \mathrm{~g}$ during the wet season and $3.06 \mathrm{~g} / 100 \mathrm{~g}$ during the dry season. The mean moisture contents during the wet and dry seasons were $71.7 \mathrm{~g} / 100 \mathrm{~g}$ and $73.45 \mathrm{~g} / 100 \mathrm{~g}$ respectively. The content was significantly higher in dry season than the wet season (Wilcoxon matched paired signed rank test, $\mathrm{W}=62.00, \mathrm{df} 11, \mathrm{p}=$ 0.0122) (Fig. 3D). Similarly, ash content was significantly higher in dry season than the wet season (Wilcoxon matched paired rank test, $\mathrm{W}=78.00, \mathrm{df}$ $11, \mathrm{p}=0.0005$ ) (Fig. 3E). The mean ash contents were $3.56 \mathrm{~g} / 100 \mathrm{~g}$ and $4.61 \mathrm{~g} / 100 \mathrm{~g}$ for wet and dry seasons respectively.
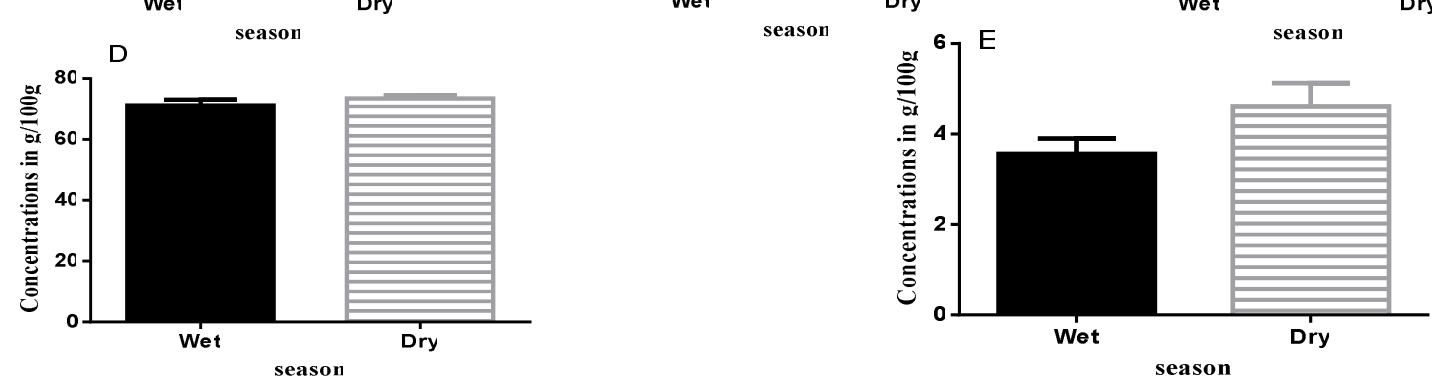

Figure 3: Seasonal variation in protein (A), Lipid (B), Carbohydrate (C), Moisture (D) and Ash (E) in O. niloticus from Lake Victoria. 
Bajopas Volume 9 Number 1 June, 2016

Protein content of $R$. argentea was significantly higher in wet season than dry season (Two sample paired $t-$ test, $\mathrm{t}=6.872$, df $=11, \mathrm{p}<0.0001$ ) (Fig. 4A). The mean contents were $19.61 \mathrm{~g} / 100 \mathrm{~g}$ and $16.13 \mathrm{~g} / 100 \mathrm{~g}$ for the wet and dry seasons respectively. Similarly, lipid content was significantly higher in wet season than dry season (Two sample paired $\mathrm{t}$ - test, $\mathrm{t}=$ 13.10, df = 11, $\mathrm{p}<0.0001$ ) (Fig. 4B).

The mean content during the wet season was 1.20 $\mathrm{g} / 100 \mathrm{~g}$ and was $0.41 \mathrm{~g} / 100 \mathrm{~g}$ during the dry season. The mean carbohydrate content during the wet season was $1.17 \mathrm{~g} / 100 \mathrm{~g}$ and was $2.15 \mathrm{~g} / 100 \mathrm{~g}$ during the dry season. The content was significantly higher in dry season than the wet season (Wilcoxon matched pairs signed rank test, $W=58, d f=11, p=$ 0.0210) (Fig.4C). Moisture content was significantly higher in dry season than wet season (Two paired $t-$ test, $t=13.71$, df $=11, p<0.0001$ ) (Fig. 4D). The mean contents were $71.52 \mathrm{~g} / 100 \mathrm{~g}$ and $76.87 \mathrm{~g} / 100 \mathrm{~g}$ for the wet and dry seasons respectively. Ash content was significantly higher in wet season than the dry season (Two paired sample t- test, $t=6.972$, df $=$ $11, p=<0.0001$ ) (Fig. 4E). The mean ash contents for the wet and dry seasons were $6.52 \mathrm{~g} / 100 \mathrm{~g}$ and 4.44 $\mathrm{g} / 100 \mathrm{~g}$ respectively.

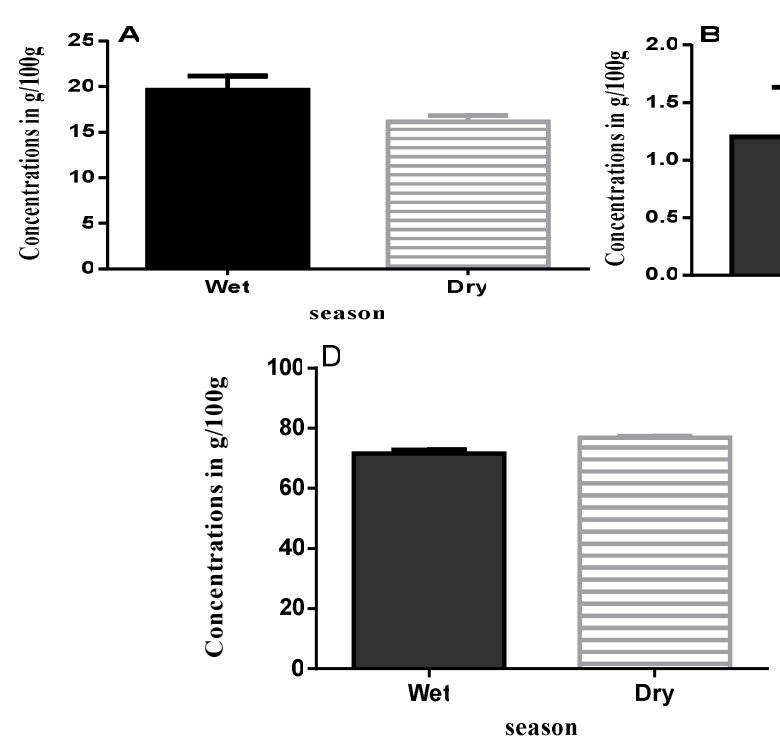

Figure 4: Seasonal variations in protein (A), Lipid argentea from Lake Victoria.

There were no significant differences in the mean protein content of $L$. miodon between the two seasons (dry and wet) (Two sample paired t- test, $t=$ 0.9756, $d f=11, p=0.3502$ ) (Fig. $5 \mathrm{~A}$ ). The mean lipid content of the species was $1.01 \mathrm{~g} / 100 \mathrm{~g}$ during the wet season and $0.79 \mathrm{~g} / 100 \mathrm{~g}$ during the dry season. The content was significantly higher in wet season than dry season (Two sample paired t- test, $t=3.115$,
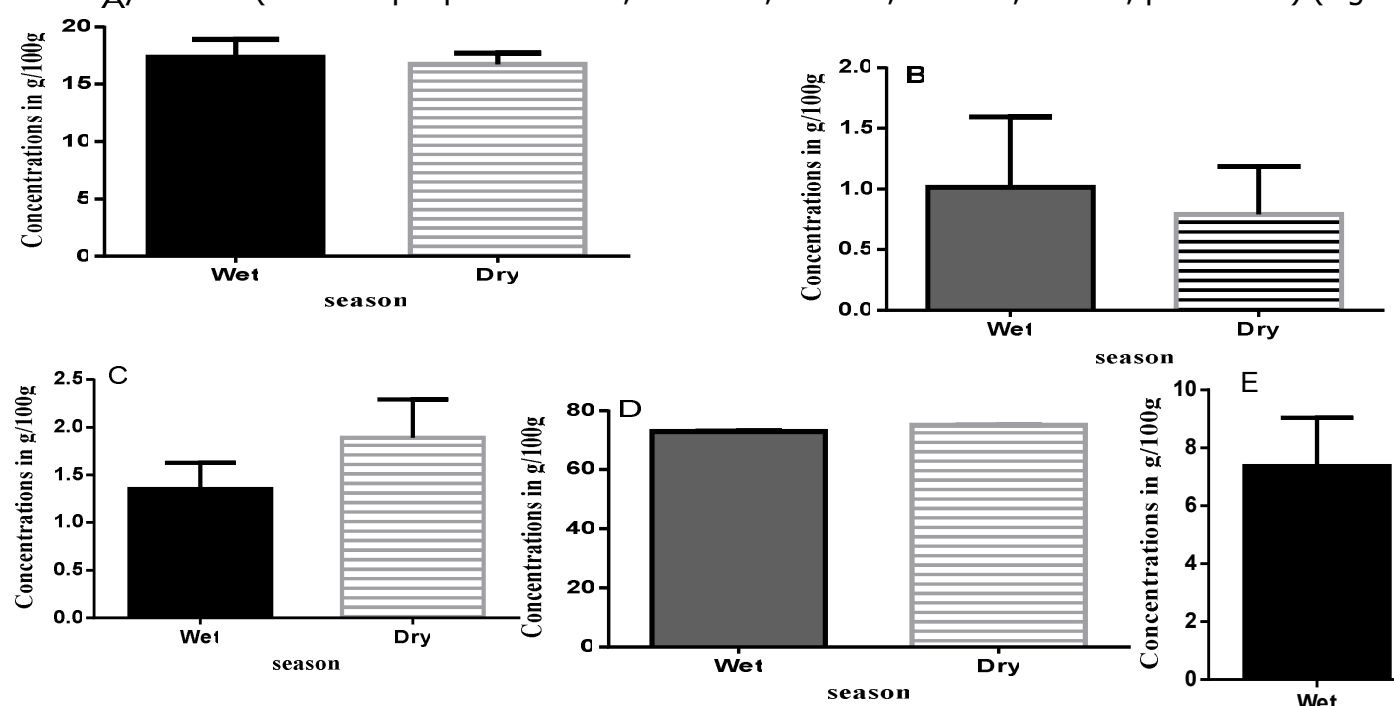

$d f=11, p=0.0098$ ) (Fig. 5B). Carbohydrate content was significantly higher in dry season than the wet season (Two sample paired $t$ - test, $t=4.103, p=$ 0.0017 ) (Fig. 5C). Moisture content was significantly higher in dry season than wet season (Two sample paired $t$ - test, $t=18.94, d f=11, p<0.0001$ ) (Fig. 5D). Ash content was significantly higher in wet season than dry season (Wilcoxon matched pairs signed rank test, $W=-66, d f=11, p=0.0063$ ) (Fig. 5E).

Figure 5: Seasonal variations in protein (A), Lipid (B), Carbohydrate (C), Moisture (D) and Ash (Es)atppry. miodon from Lake Tanganyika. 
The mean protein content of $S$. tanganicae was significantly higher in wet season than dry season (Wilcoxon matched pairs signed rank test, $W=-78$, $\mathrm{df}=11, \mathrm{p}=0.0005$ ) (Fig. 6A). The mean lipid content was significantly higher in wet season than dry season (Two sample paired $\mathrm{t}$ - test, $\mathrm{t}=3.441, \mathrm{df}=11, \mathrm{p}=$ 0.0055) (Fig. 6B). Carbohydrate content was significantly higher in dry season than the wet season
(Wilcoxon matched pairs signed rank test, $\mathrm{W}=78$, $\mathrm{df}=11, \mathrm{p}=0.005$ ) (Fig. 6C). Similarly, moisture content was significantly higher in dry season than the wet season (Two sample paired $t-$ test, $t=3.044$, $\mathrm{df}=11, \mathrm{p}=0.0112$ ) (Fig. 6D). Ash content was higher in dry season than wet season, but not significantly different (Two paired sample $t-$ test, $t=0.9695$, $d f=11, p=0.3531)$ (Fig. 6E).

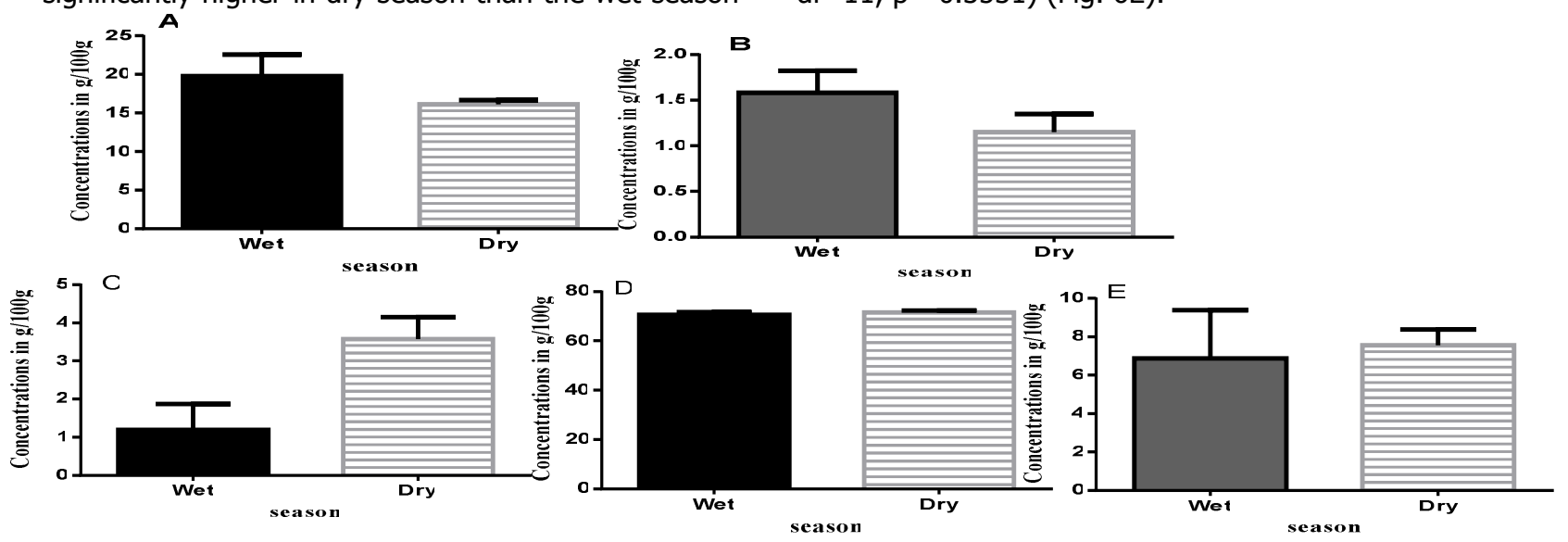

Figure 6 Seasonal variations in protein (A), Lipid (B), Carbohydrate (C), Moisture (D) and Ash (E) in $S$. tanganicae from Lake Tanganyika.

\section{DISCUSSION}

Fish of various species do not provide the same proximate and mineral compositions to their consumers (Takama et al., 1999). The nutritive values of fishes differ with seasons (Varljen et al., 2013). In the present study samples were captured on the preselected seasons to determine the most appropriate season for utilization.

The biochemical constituents in animals are known to vary with season, size of the animal, stage of maturity and availability of food. The present study accepts the hypothesis that there are significant seasonal variations in the proximate compositions of the five species of fishes. The protein contents of all the five fish species were significantly higher $(P<0.05)$ during the rainy season. This conforms to the work of Abdullahi and Abolude (2001) that studied nutrient levels of Bagridae in relation to season from Nigeria. The study also conforms to the work of Abdullahi (2002) who studied seasonal and locational variations in proximate composition among $L$. niloticus, $H$. niloticus and G. niloticus. The study also agreed with the work of Tzikas et al., (2005) who reported high contents of protein during the wet season. This result was not in accordance to the findings of Connel (1980), Abdullahi and Abolude (2002) and Abdullahi (2005) who reported low level of protein during the rainy season. Narcisa et al. (2001) also reported that protein content remained fairly constant during the whole year period in horse mackerel (Trachurus trachurus). Similarly, the lipid content was significantly higher $(\mathrm{P}<0.05)$ in all the species during the rainy or wet season. These are comparable to the reports of Dawson (1980); Craig (1977) and Shulman, (1984); in various temperate fishes and Abdullahi
(2002) in Nigeria. Most fishes breed during the wet season, therefore the high content of fat and protein in the species were attributed to their utilization for gonad development, hormonal changes, egg developing and subsequent breeding activities. The mean values of carbohydrate were significantly higher during the dry season in all the species. This was supported by work of Abdullahi, (2005). The higher content of carbohydrate during the dry season may be due to it usage for physiological processes and subsequent starvation period after spawning (Connell, 1980, Pussey and Kennard, 1996). The mean value of the moisture content in the species ranged between $(71.04$ to $74.19 \mathrm{~g} / 100 \mathrm{~g}$. Since water constitutes about $70 \%$ of every living cell, the fish showed tendency toward maintaining such level irrespective of the seasons. The ash content was significantly lower $(P<0.05)$ during the rainy season and high during the dry season in $L$. niloticus and $O$. niloticus. This agreed with work of Abdullahi (2002); Abdullahi (2005) but do not conform to the work of Abdullahi and Abolude, (2005). The low mean ash content recorded may be explained by the possibility that absorption occurred during the rainy season and gradually accumulated to its peak during the dry season.

\section{CONCLUSION}

This study has revealed that $L$. niloticus, $O$. niloticus, $R$. argentea, $S$. tanganicae and $L$. miodon are rich in protein, have average to lean lipid contents and low carbohydrate contents which might be useful for normal growth, development and as a remedy to nutritional and health related problems. In addition, the higher levels of protein and fats or lipids during the rainy season make the species highly desirable for consumption during this period. 


\section{Acknowledgement}

The author acknowledge Umaru Musa Yar,adua University (UMYU), Katsina State, Nigeria for the grant and Mr. Muffui Gedalia of the Department of

\section{REFERENCES}

Abdulkarim, B. and Abdullahi, S. A. 2009 Studies on the proximate and mineral content analysis of three fresh water fishes of the families Schilbedae, Mormyridae and Mochokidae in Mairuwa Reservoir, Faskari, Katsina State Nigeria. Katsina Journal of Pure and Applied Sciences 1: 17-22.

Abdullahi, S. A. (2002). Seasonal and locational variations in the proximate, amino acid and mineral contents of Lates niloticus, Heterotis niloticus and Gymnarcus niloticus in Nigeria. Journal of Agriculture and Environment, 3:(2) 359-366.

Abdullahi, S. A. (2005). Seasonal study on nutrient variability of the electric catfish (Malapterurus electricus Gmelin) obtained from three sites of the Nigerian Savannah. Journal of Tropical Biosciences, 5: 62-65.

Abdullahi, S. A. and Abolude, D.S. (2000). Studies on the effect of season and geographical location on nutrient content of two fish families (Cichlidae and Claridae). Nigerian Journal of Experimental and Applied Biology, 12: 117123.

Abdullahi, S. A. and Abolude, D.S. (2005). Seasonal levels of some nutrients in the three Bagrids from two localities in Northern Nigeria. Nigerian Journal of Scientific Research, 5 :(2) 43-47.

Ackman, R. G. (1989). Nutritional composition of fats in sea food programme. Nutritional Science, 13: $161-241$.

AOAC. (1990). Association of Official Analytical Chemist. Official Methods of Analysis of the AOAC 17th Edn. Arlington, V.A. U.S.A., 9 : 140250.

Bhuiyan, A. K. M., Ratnayake, W.M.N. and Ackman, R.G. (1993). Nutritional composition of raw and smoked Atlantic Mackerel (Scomber scombrus): oil-water soluble vitamins. Journal of Food Composition and Analysis, 6: 172 - 184.

Bolawa, O. E., Gbenle, G.O, Ayodele, S.O., Adewusi, O.R., Mosuro, A.O. and Apata, O.S. (2011). Proximate Composition Properties of Different Fish Species Obtained from Lagos, Nigeria. Internet Journal of Food Safety 13: 342-344.

Connell, J. J. (1980). Advances in Fish Science and Technology. Fishing News books, Farnham, Surrey 513p.

Conquer, J. and Holub, B.J. (2002). Human health effects of docosahexaenic acid in: J. Shi, G. Mazza and M.L. Maguer (eds). Functional foods: Biochemical and Proceeding Aspects. Vol. 2. CRC Bocaraton. Pp 311-329.

Craig, M. (1977). The body composition of adult perch (Perca fluviatilis) in Windermere with reference to seasonal changes and reproduction. Journal of Animal Ecology, 40 : 633-652.
Animal Sciences and Production, Sokoine University of Agriculture (SUA), Morogoro, Tanzania for his Technical assistance.

Dawson, N., and Grimam, A. S. (1980). Qualitative seasonal changes in protein, lipid and energy content of the carcass, ovaries and liver of female Plaice (Phenonectes platessa). Journal of Fish Biology, 16: 493-509.

FAO. (2000). The state of world fisheries and aquaculture. Rome : food and Agricultural organisation of the United Nations. http:www. fao.org/sof/sofia/index_en.htm.

Fawole, O. O., Ogundiran, M.A., Ayandiran, T.A. and Olagunju, O.F. (2009). Proximate and mineral Composition determinations in Some Selected Fresh water Fishes in Nigeria. Internet Journal of Food Safety 9: 52-55.

Huss, H. H. (1988). Fresh fish - quality and quality changes, FAO Fisheries reports Series No. 29, FAO, Rome, Italy, pp. 28-59.

Huss, H. H. (1999). Quality and quality changes in fresh fish, FAO Fisheries Technical Paper No. 348. FAO, Rome, Italy, pp. 20-92.

Kent, G. (1984). Fish and Nutrition in India. Food Policy 2 (2): 161-175.

Lake, B. (1984). Principles of Fish Nutrition and Diet Therapy, Little Brown. Boston. 176pp.

Love, R. M. (1980). The Chemical Biology of fishes, New York, Academic press. p 467.

Murray, J. and Burt, J. R. (2001). The Composition of Fish. Torry Advisory Note No. 38, Ministry of Technology. Torry Research Station, U.K., 14 pp.

Narcisa, M. B. Irineu, B., Maria, L. and Jose, M.E. (2001). Seasonal variation in the chemical composition of horse-mackerel (Trachurus trachurus). Food Research and Technology 212: 535-539.

Noel, L., Chafey, C., Testu, C., Pinte, J., Velge, P. and Guerin, T. (2011). Contamination levels of Lead, Cadmium and Mercury in imported and domestic lobsters and large crab species consumed in France. Differences between white and brown meat.Journal of Food Composition and Analysis. 24:368-375

Okeyo, G. O., Lokuruka, M.N.I. and Matofari, J.W. (2009). Nutritional Composition and Shell Life of the Lake Victoria Nile perch (Lates niloticus) Stored in Ice. African Journal of Food, Agriculture, Nutrition and Development 1: 1-5.

Oyebamiji, O.F., Fagbohun, T.R. and Olubanju, O.O. (2008). Nutrient Quality of Traditional Smokedried Fresh Water Fish. Turkish Journal of Fisheries and Aquatic Sciences, 8: 7-13.

Pussey, B. J. and Kennard, M.J. (1996). Species richness and geographical variation of assemblage structure of the fresh water fish fauna of the wet tropics region of Northern Queensland. Marine Fresh Water Research, 47: 563-573. 
Shulman, M. (1980). Biochemical Circles in Fish, New York, John Wiley and sons, Landhulsted, $\mathrm{p}$ 20-12.

Sven, E. J., Gaspard, N. and Sixtus, K. (2006). Lake Tanganyika: Experience and lessons learned brief. P 363-376. Retrieved 15th September, 2012 from www. google.com

Takama, K., Suzuki, T., Yoshida, K., Arai, H. and Mitsui, T. (1999). Phosphatidylcholine levels and their fatty acid compositions in Teleost tissues and squid muscle. Biochemistry Molecular Biology, 124: 109-116.

Tobor, J.G. (1984). A review of the fish industry in Nigeria and status of fish preservation methods and future growth pre-requisites to cope with anticipated increase in production. NIOMR Tech. Paper. 17:14pp

Tzikas, Z., Amvrosiadisa, I., Soultos, N. and Georgakisa, S.P. (2007). Seasonal variation in the chemical composition and microbiological condition of Mediterranean horse muscle from the North Aegean sea (Greece). Food control, 18 : (3) 251-257.
Varljen, J., Sulic, S., Brmalj, L., Obersnel, V. and Kapovic, M. (2013). Lipid classes and fatty acid composition of Diplodus vulgaris and Conger conger originating from Adriatic sea. Food Technology Biotechnology, 41: 149156

Waterman, J. J. (2000). Composition and Quality of Fish, Edinburgh, Torry Research Station.

Witte, F. and Van Densen, W.L.T. (1995). Fish Stocks and Fisheries of Lake Victoria. Samara publishing Limited, Canada, Great Britain. 404p. 